\title{
Giant penile elephantiasis after circumcision: a devastating complication
}

\author{
Jai Prakash, Manoj Kumar, Vishwajeet Singh, Satyanarayan Sankhwar
}

Department of Urology, King George Medical University, Lucknow, Uttar Pradesh, India

Correspondence to Dr Jai Prakash,

drjpswami@gmail.com
To cite: Prakash Kumar $\mathrm{M}$, Singh $\mathrm{V}_{\text {, et al. }}$ BMJ Case Rep Published online: [please include Day Month Year] doi:10.1136/ bcr-2013-200780

\section{DESCRIPTION}

A 45-year-old man presented with a history of circumcision carried out a year ago owing to phimosis. One week after the circumcision he developed a small nodular swelling over the corona that had gradually increased in size. $\mathrm{He}$ also had intermittent fevers and tenderness for the last month before presentation. Physical examination showed involvement of the whole glans and the distal penile shaft by swelling, which was firm to soft in consistency, meatus was buried in swelling and inguinal nodes were not palpable (figure 1A, B).

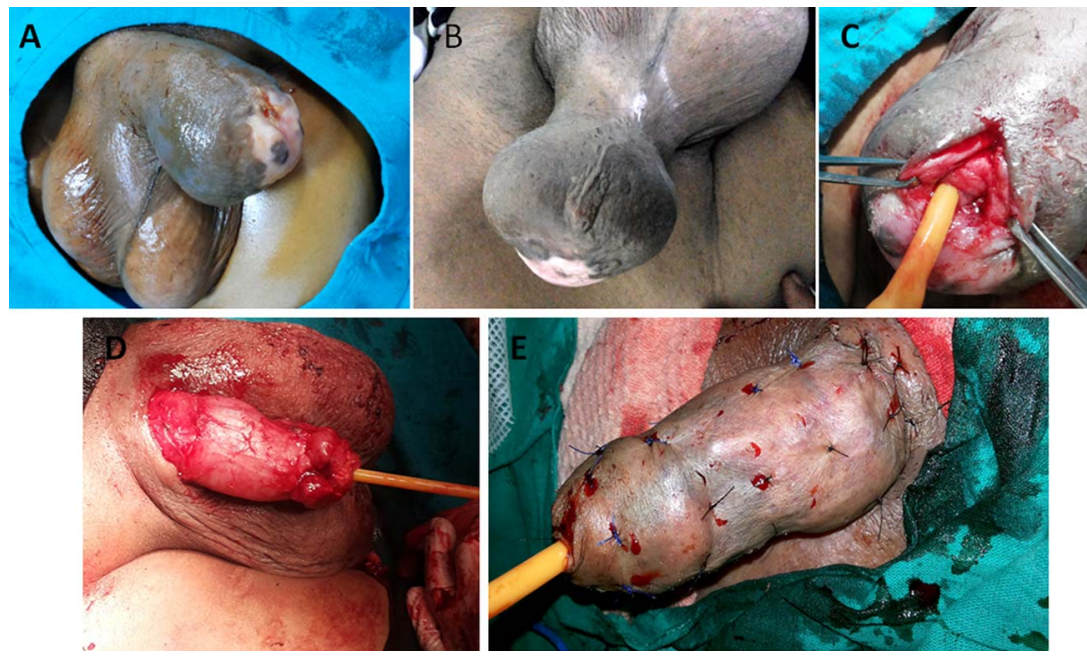

Figure 1 Swelling involves glans and distal shaft: (A) dorsal view and (B) ventral view. (C) Buried meatus seen after dorsal split. (D) Denuded penis after excision of skin and subcutaneous tissue and (E) final appearance of penis after application of split skin graft.
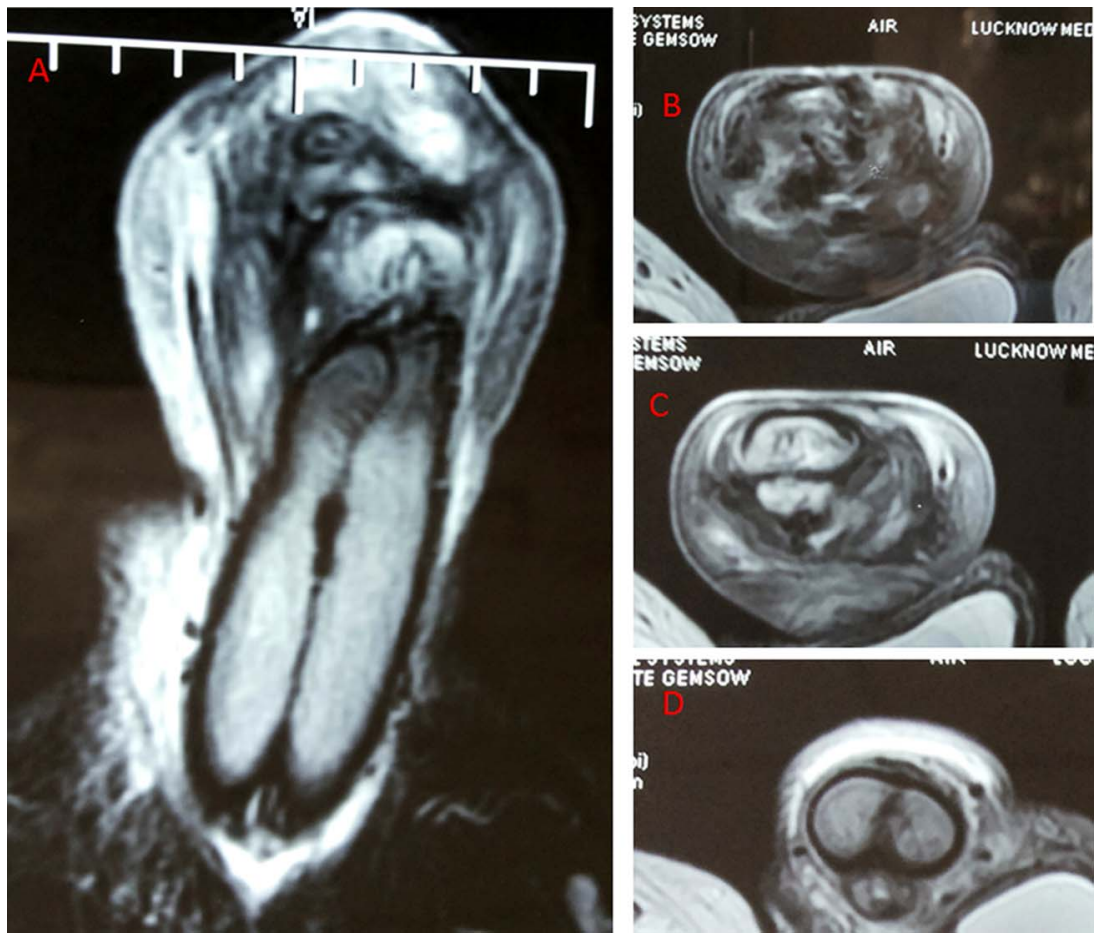

Figure 2 MRI showing soft tissue thickening and loss of fascial planes in glans and penile shaft, normal corpora cavernosa and spongiosa: (A) coronal view. Transverse section at the level of (B) glans, (C) corona and (D) distal shaft. 

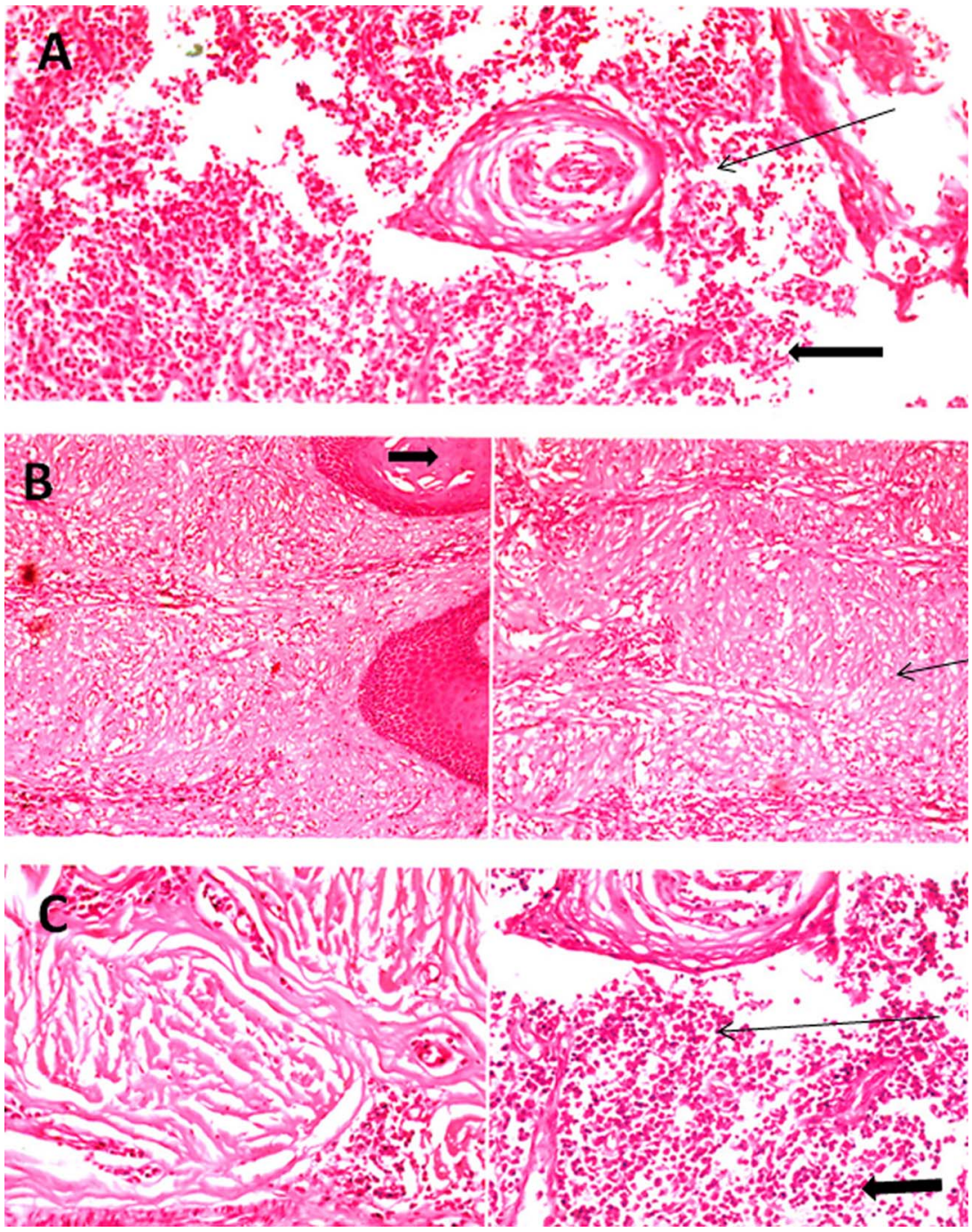

Figure 3 Histopathology showing (A) oedematous stroma (long arrow) and inflammatory cells (small arrow), (B) fibrosis (long arrow) and epidermis (small arrow), and (C) microabscesses (long arrow) and stromal oedema (small arrow).

Routine blood investigation, urine microscopy and culture, and chest X-ray were within normal limits. Peripheral blood smear for microfilaria and ELISA for microfilarial antigen were negative. MRI was suggestive of soft tissue thickening and loss of fascial planes in glans and penile shaft (figure 2). He underwent excision of whole penile skin and subcutaneous tissue followed by split skin grafting (figure 1C-E). Histopathology revealed marked acute on chronic inflammation with fibrosis and stromal oedema (figure 3 ).

Lymphoedema of the external genitalia may be caused by infections, neoplasms, chronic inflammation or rarely congenital. ${ }^{1}$ Congenital lymphoedema rarely have isolated involvement of external genitalia. ${ }^{1}{ }^{2}$ Filariasis is the most common acquired cause. ${ }^{2}$ Bacterial infection may lead to abscesses and sinus formation ${ }^{3}$ or lymphoedema ${ }^{2}$ of the skin and subcutaneous tissue by involvement of the apocrine sweat glands with resultant hidradenitis suppurativa. ${ }^{2}$ In initial stages when there is no permanent damage to the skin, lymphatics and subcutaneous tissue, conservative treatment may be tried ${ }^{2}$ but in chronic conditions because of permanent pathological changes surgical procedure is required. $^{2}$

\section{Learning points}

Elephantiasis of the external genitalia:

- May be caused by infections and chronic inflammation after iatrogenic trauma.

- In early stages conservative may be sufficient.

- In chronic conditions because of permanent pathological changes surgical procedure is required.

Competing interests None.

Patient consent Obtained.

Provenance and peer review Not commissioned; externally peer reviewed.

\section{REFERENCES}

1 Smeltzer DM, Stickler GB, Schirger A. Primary lymphedema in children and adolescents: a follow-up study and review. Pediatrics 1985;76:206-18.

2 Mc Dougal WS. Lymphedema of the external genitalia. J Urol 2003;170:711-16.

3 Ramesh V, Ramesh V. Lymphoedema of the genitalia secondary to skin tuberculosis: report of three cases. Genitourin Med 1997:73:226-7. 
Copyright 2013 BMJ Publishing Group. All rights reserved. For permission to reuse any of this content visit http://group.bmj.com/group/rights-licensing/permissions.

BMJ Case Report Fellows may re-use this article for personal use and teaching without any further permission.

Become a Fellow of BMJ Case Reports today and you can:

- Submit as many cases as you like

- Enjoy fast sympathetic peer review and rapid publication of accepted articles

- Access all the published articles

- Re-use any of the published material for personal use and teaching without further permission

For information on Institutional Fellowships contact consortiasales@bmjgroup.com

Visit casereports.bmj.com for more articles like this and to become a Fellow 